\title{
A Comparative Study of the Sensitivity of Selected Aquatic Plants to Mining Effluents
}

\author{
R. C. F. Ferreira \& M. A. S. Graça \\ Departamento de Zoologia, Universidade de Coimbra. 3004-5 17 Coimbra. Portugal. \\ Correspondence to: M. A.S. Graça (mgraca@ci.uc.pt)
}

\begin{abstract}
Information is given on the relative sensitivity oftwo species of algae and three species ofmacrophytes to two effluents from a mining industry. As endpoints we used growth and radicle development. Algal (Ankistrodesmus bibraianus) growth and macrophyte radicle development endpoints were more sensitive than plant growth estimates, both weight and length. Chara globuluris was the least pollution-sensitive species, with the highest number of low or undetectable toxicity effects. Radicle development of Myriophyllum spicatum was more pollution-sensitive than that of Ranunculus sp. And also than the population growth of $A$ bibraianus. Their ease of use and sensitivity to pollution suggest that macrophytes have a great potential as tools for the development of water quality criteria.
\end{abstract}

Keywords: macrophyte, ecotoxicological tests, mine effluents, root development.

\section{RESUMEN}

Se estudió la sensibilidad relativa de dos especies de algas y tres especies de macrófitas a contaminantes (efluentes de industria minera). Como indicadores se usaron el crecimientoy el desarrollo de la radicula (cuando aplicable). El crecimiento algal (Ankistrodesmus bibraianus) así como el desarrollo radicular, fueron más sensibles que los indicadores de crecimiento (en peso o longitud) de las macrófitas. Chara globularis fue la especie menos sensible. El desarrollo radicular de Myriophyllum spicatumfue considerado más sensible que el desarrollo de radicula de Ranunculus sp. y que el crecimiento populacional de A. bibraianus. Lufacilidad con que las macrófitas se pueden manipular así como su sensibilidad sugieren su potencial utilización en el establecimiento de criterios de calidad de las aguas.

Palabras clave Macrófitas, tests ecotoxicológicos, efluentes de minas desarrollo radicular.

\section{INTRODUCTION}

Invertebrates and fish have been frequently used to determine the potential toxicity of effluents and wastewaters, with photosynthetic organisms being restricted to a few testing species. However, the potential of aquatic plants as indicators of water quality has increasingly been recognised (see Lewis \& Wang, 1997; Mohan \& Hosetti, 1999). Algae and aquatic plants play a key role in aquatic ecosystems because they are at the base of food webs. Also, they are a food resource and provide oxygen and shelter for many aquatic organisms. They also contribute to the stabilisation of sediments and bioconcentration of compounds (Gobas et al., 1991) and are used as bioremediatives (Salt et al., 1995).

Algae have been reported as equally or more setisitive than animals (Lewis, 1992) and have been widely used in toxicity tests for regulatory purposes (e.g., ISO 1987; Weber et al., 1989). However, algae may not necessarily be an indicator of overall aquatic plant sensitivity to pollution. In fact, some studies have shown a higher sensi- 
tivity of macrophytes compared to algae and animals (Thomas et al., 1986; Roshon et al., 1999).

Mining activities generally result in the increase of heavy metals and the decrease in $\mathrm{pH}$ of receiving waters, with a concomittant reduction in invertebrate density and diversity and changes in functional parameters of streams (Amisah \& Cowx, 2000; Cherry et al., 2001; Niyogi et al., 2001). Analogous effects have been observed in Iberian streams affected by inining activities (e.g. Garcia Criado \& Fernandez Alaez, 2001; Marques et al., 2001). Mine effluents with high $\mathrm{pH}$ have also been reported, with similar effects on the structure of macroinvertebrate communities (Coimbra et al., 1996).

The objective of this study was to determine the relative sensitivity of two species of algae (Ankistrodesmus bibraianus (Reich) Korsikov and Chara globularis var. globularis Thuill) and three species of macrophytes (Elodea canadensis Michaux, Myriophyllum spicatum L. and Ranunculus sp.) to two high-pH effluents from a mining industry. This knowledge is relevant because the effects of high-pH mining effluents are not well known.

\section{MATERIALS AND METHODS}

For the experiments we used effluent waters from a mine in Alentejo, Portugal. The waters had a high conductivity, high content in sulphates and nitrates. High $\mathrm{pH}$ lead to low heavy metal levels in the water. Discharge of mining effluents caused a decrease in the number of invertebrate taxa in the stream and a change in community structure with the replacement of taxa using dissolved oxygen from the water by taxa using atmospheric oxygen (see Coimbra et al., 1996).

As test organisms, we used the microalga Ankistrodesmus bibraianus (Reich) Korsikov, the macroalga Chara globularis var. globularis Thuill and the macrophytes Elodea canadensis Michaux, Myriophyllum spicatum L. and Ranunculus sp. The microalga $A$. bibraianus was selected because it has been widely used in toxicity tests (e.g. Fairchild et al., 1998). The macrophyte $E$. canadensis was used because it is easy to grow and was available during all year. The other plant species selected for experiments were indigenous to the study area.

A. bibraianus (also called Selenastrum capricornutum Printz) used in experiments was obtained from the algal culture collection of the Department of Botany, University of Coimbra (ACOI No164). Toxicity tests were conducted following standard procedures of the U.S. Environmental Protection Agency (Weber et al., 1989). The tests started with the addition of an axenic population of $A$. bibraianus to several dilutions of the testing sample and to a control (i.e. pure culture medium, with no algae). After 96 hours of exposition, algal cells were counted in each concentration treatment using a haemacytometer (Neuebauer). Test conditions are summarised in Table 1.

The macroalga $C$. globularis and the macrophytes $M$. spicatum and Ranunculus sp. were collected from a non-impacted area of the stream. $E$. canadensis was provided by the Department of Botany (University of Coimbra, Portugal). Test procedures using macroalgae and macrophytes are from Detenbeck et al. (1996) and Fairchild et al. (1998). Apical growth tips of macroalgae and macrophytes were cut, their length measured and wet weights obtained (precision $\pm 0.001 \mathrm{~g}$ ). Growth tips were then added to several concentrations of the test sample. After 21 days of exposition, plant segments were weighed (wet weight) and length and radicle growth measured (i.e. the sections used had no radicle at the beginning of the test). Shoot length of $M$. spicatum was not measured and $C$. globularis has no radicle. Macrophytes were acclimated to test conditions for 1 week (see Table 1).

We used two test samples, i.e. tailings and mine waters. Mine water chemistry varied throughout the year. Conductivity ranged between 2,130 and $3,120 \mathrm{mS} \mathrm{cm}^{-1}$, sulphate concentration range $609-1,000 \mathrm{mg} \mathrm{L}^{-1}$, nitrate concentration was 109 - $136 \mathrm{mg} \mathrm{L}^{-1}$, and oxygen saturation varied between 51 and $100 \%$, while $\mathrm{pH}$ was between 7.0 and 8.9. Copper was the only heavy metal at detectable levels, concentrations ranging from $<17 \mu \mathrm{g} \mathrm{L}$-' up to $28 \mu \mathrm{g} \mathrm{L}-'$. 
Table 1. Summary of the test conditions for chronic toxicity tests on microalgae (Ankistrodesmus bibraimus) and macroalgae/macrophytes (Chara globularis, Elodea canadensis, Myriophyllum spicatum and Ranunculus sp.). Resumen de las condiciones experimentales pura la microalga (Ankistrodesmus bibrainus) y macroalga/macrófinas (Chara globularis, Elodea canadensis. Myriophyllum spicatum ana Ranunculus sp.) en experimentos de respuesta crónica.

\begin{tabular}{lll}
\hline & Microalgae & Macroalgae/Macrophytes \\
\hline Test type & Static & Static \\
Test duration & 96 hours & 21 days \\
Temperature & $25 \pm 1^{\circ} \mathrm{C}$ & $25 \pm 1^{\circ} \mathrm{C}$ \\
Light source & Cool-white fluorescent & Cool-white tluorescent \\
Photoperiod & Continuous illumination & $16: 8$ (light:dark) \\
Test chamber & $250 \mathrm{~mL}$ Erlenmeyers & 500 mL Erlenmeyers \\
Test volume & $50 \mathrm{~mL}$ & 200 mL \\
Organisms age & $4-7$ days & 5 cm apical shoots \\
Initial organism number/size & 10,000 cells mL ${ }^{-1}$ & S \\
Replicates & 4 & River water (upstream) \\
Dilution water & Algal culture medium & Every 7 days \\
Water renewal & None & None \\
Aeration & None & $0,10,20,40,80$ \\
Concentrations $(\%)$ & $0,5,10,20,40,80$ & Wet weight increase \\
Endpoint & Population growth (as cell number) & Shoot length increase
\end{tabular}

Fe was occasionally present, too. For tailing waters, conductivity ranged between 3,120 and $4,690 \mathrm{mS} \mathrm{cm} \mathrm{cm}^{-1}$, sulphate concentration was between 930 and $1,620 \mathrm{mg} \mathrm{L}^{-1}$, nitrate concentration varied between 16 and $68 \mathrm{mg} \mathrm{L}^{-1}$, oxygen saturation ranged $32-61 \%$ and $\mathrm{pH}$ was between 6.9 - 11.1. Copper was the only heavy metal detected in samples, with concentrations ranging from $<17 \mu \mathrm{g} \mathrm{L}^{-1}$ to $52 \mu \mathrm{g} \mathrm{L}^{-1}$. Only treated mine waters have been discharged into the environment. Samples were collected, transported to the laboratory in a cooling bag, refrigerated at $4{ }^{\circ} \mathrm{C}$ and analysed within 24 hours. We estimated an IC50 (i.e. percentage of sample inhibiting $50 \%$ of the test endpoint) according to EPA procedures (Weber et al., 1989). IC50 values were converted to toxicity units (TU50=100/IC50; Lewis et al., 1982). Relative sensitivity of test species to the mine waters tested was determined by ranking the data, assigning high scores to the most pollution-sensitive species and low scores to the least sensitive. A general rank was computed by summing the scores of both tests.

\section{RESULTS}

Sensitivity to mine and tailing waters was compared in terms of toxicity units (TU50), as shown in Figure 1. The highest toxicity (i.e. TU50 > 10) were found on radicle growth of $M$ spicatum. Lowest toxicity effects values ranged between 1.2 TU50 and non-detectable for the length and weight of $C$. globularis, weight of $M$ spicatum and length and weight of Ranunculus sp. (not displayed on the plot).

Toxicity of mine water and tailings was similar. However, the toxic effect of tailings was strongest on Ranunculus sp. radicle growth and A. bibraianus population growth. Conversely, the inhibiting effect of mine water was strongest upon E. canadensis and $M$ spicatum radicle growth. The relative sensitivity can be ranked in the following way: $\operatorname{Ms}(\mathrm{R})>\operatorname{Rs}(\mathrm{R})>\mathrm{Ab}(\mathrm{G})>$ $\mathrm{Ec}(\mathrm{R})=\mathrm{Ec}(\mathrm{L})>\mathrm{Ec}(\mathrm{W})$.

Algal growth and macrophyte radicle development were more sensitive in toxicity tests than plant growth was. Plant growth was estimated 
either from plant weight or from plant length. $C$. globularis was the least sensitive species, with the highest number of very low or non-detectable toxicity endpoints. The radicles of $M$. spicatum developed substantially more than those of Ranunculus sp. and more than the population growth of A. bibraianus.

\section{DISCUSSION}

An important step in the assessment of water pollution and bioremediation is the characterization of polluters in terms of (a) toxicity and (b) ecological effects in the receiving system. Sensitivity, ease of use and standardization are important aspects of ecotoxicological tests.

In terms of sensitivity to toxic substances, the three highest endpoints we obtained in tests were growth of the alga $A$. bibraiamus and the radicle development of macrophytes. Our results confirm previously published information on the sensitivity of $S$. capricornutum (e.g. Fairchild et $a l ., 1998)$ and radicle development (Guillizonni,
1991; Fargašová, 1998). Mine wastewaters are generally a mixture of inorganic compounds. Concentration of sulphates and nitrates are invariably high (Coimbra et al., 1996). Heavy metals are typically below the detection level but occasional peaks have been registered. Here, maximum $\mathrm{Fe}$ and $\mathrm{Cu}$ concentrations were 400 and $270 \mu \mathrm{g} \mathrm{L}^{-1}$, respectively. Algae and macrophytes are sensitive to low concentrations of heavy metals. Deanovic et al., (1999) found that $8 \mu \mathrm{g} \mathrm{L}^{-1} \mathrm{Cu}$ inhibited $50 \%$ of $S$. capricornutum growth. Also, a $50 \%$ reduction in radicle development of $M$. spicatum has been found at a concentration of $250 \mu \mathrm{g} \mathrm{L}^{-1} \mathrm{Cu}$ (Guillizonni, 1991).

Standardization is essential to reduce variability. The algal inhibition test using S. capricornutum has been widely used in test batteries for regulatory purposes. This test is simple, fast, sensitive, economical and reproducible.

On the other hand, selection of testing organisms is also based on the ease of use and culture. Among the tested organisms, E. canadensis was easy to maintain in the laboratory during all year, had a fast growth rate and was sensitive to toxi-

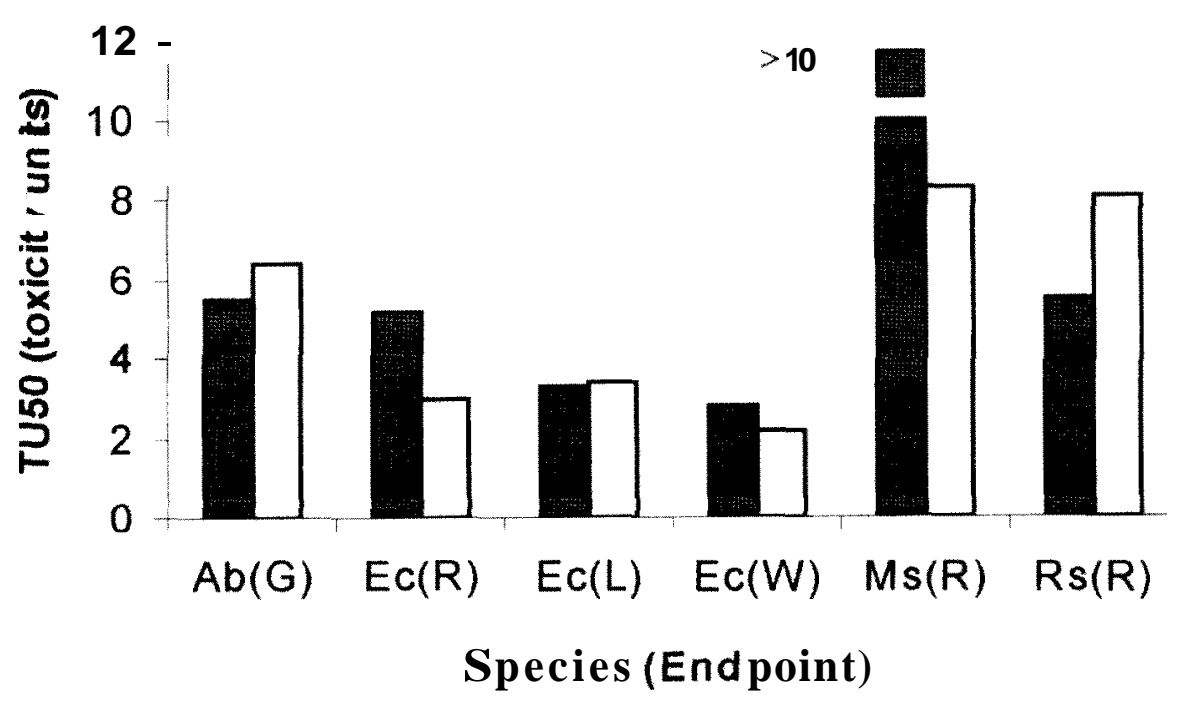

Figure 1. Comparative toxicity of 2 industrial effluents to the microalgae Ankistrodesmus bibraianus (Ab) and the macrophytes Elodea Canadensis (Ec), Myriophyllum spicatum (Ms) and Ranunculus sp. (Rs). Endpoints: population growth (G); shoot length (L); wet weight (W) and radicle length (R). Respuesta ecotoxicológica de la micro alga Ankistrodesmus bibraianus (Ab) y las macrófitas Elodea canadensis (Ec), Myriophyllum spicatum (Ms), Ranunculus sp. (Rs) a 2 efluentes industriales. Los parámetros medidos fueron: El crecimiento poblacional (G), tamaño de los secciones de las plantas (L), peso húmedo $(W)$ y tamaño de los raíces $(R)$. 
cants, as indicated by several endpoints. $M$. spicatum was also a robust macrophyte, it was sensitive, easy to manipulate and maintain in the laboratory and has been recommended for toxicity tests (Lewis, 1993). However, we observed high variability in the measurements of $M$. spicatum endpoints. Although the radicle development of Ranunculus sp. was a sensitive toxicity indicator, both Ranunculus sp. and C. globularis were difficult to maintain in the laboratory and growth only occurred seasonally.

Tests with macrophytes have some advantages over algal tests. Macrophyte cultures are easy to maintain, are suitable for testing toxicity of turbid samples and several other test media, and provide many endpoints to indicate toxicity. Tests can be conducted either in the laboratory or in situ (Wang, 1992; Graça et al, 2002). However, available data on these tests are scarce, due to the absence of standard test methods and culture techniques and to the lack of information on sensitive species.

Macrophytes are ideal test organisms for situations of pollution by herbicides or other inhibitors of plant growth. Therefore, there is a need for the development of standard protocols and for more information on procedures and sensitivities. Based on our experiments with industrial effluents, we conclude that radicle development is a good endpoint for toxicity tests with macrophytes. Further experimentation is still needed to determine the role of macrophytes in developing water quality criteria and the environmental relevance of the toxicity tests with macrophytes.

\section{ACKNOWLEDGEMENTS}

We thank the IMAR for allowing use of their general laboratory facilities. The help of Nuno Coimbra was fundamental in several stages of the experiments. We would also like to thank the Laboratory of algae and Botanic Garden of the Department of Botany (University of Coimbra, Portugal) for providing test organisms.

\section{REFERENCES}

AMISAH, S. \& 1. G. COWX. 2000. Impacts of abandoned mine and industrial discharges on fish abundance and macroinvertebrate diversity of the upper River Don in South Yorkshire, UK. J. Freshw. Ecol., 15:237-250

CHERRY, D. S., R. J. CURRIER, D. J. SOUCEK, H. A. LATIMER \& G. C. TRENT. 2001. An integrative assessment of a watershed impacted by abandoned mined land discharges. Env. Pollut., 111:377-388.

COIMBRA, C. N., M. A. S. GRAÇA \& R. M. CORTES. 1996. The effects of a basic effluent on macroinvertebrate community structure in a temporary Mediterranean river. Environ. Poll., 94:301-307.

DEANOVIC, L., V. M. CONNOR, A. W. KNIGHT \& K. J. MAIER. 1999. The use of bioassays and toxicity identification evaluation (TIE) procedures to assess recovery and effectiveness of remedial activitiec in a mine drainage-impacted stream system. Arch. Environ. Contam. Toxicol., 36: 21-27.

DETENBECK, N.E., R. HERMANUTZ, K. ALLEN \& M. C. SWIFT. 1996. Fate and effects of the herbicide atrazine in flow-through wetland mesocosms. Environ. Toxicol. Chem., 15: 937-946.

FAIRCHILD, J.F., D. S. RUESSLER \& A. R. CARLSON. 1998. Comparative sensitivity of five species of macrophytes and six apecies of algae to atrazine, metribuzin, alachor and metalachor. Environ. Toxicol. Chem., 17: 1830-1834.

FARGAŠOVÁ, A. 1998. Root growth inhibition, photosynthetic pigments production, and metal accumulation in Sinapsis alba as the parameters for trace metals effect determination. Bull. Environ. Contam. Toxicol., $61:$ 762-769.

GARCIA CRIADO, F. \& M. FERNANDEZ ALAEZ. 2001. Hydraenidae and Elmidae assemblages (Coleoptera) from a Spanish river basin: good indicators of coal mining pollution? Arch. Hydrobiol, 150: $641-660$.

GOBAS, F.A.P.C., E. J. MCNEIL, L. LOWETTDOUST \& G. D. HAFFNER. 1991. Bioconcentration of chiorinated aromatic hydrocarbons in aquatic macrophytes (Myriophyllum spicatum). Environ. Sci. Technol. 25: 924-929.

GRAÇA, M.A.S., A. RODRIGUES CAPÍTULO A., C. OCÓN \& N. GÓMEZ. 2002. In situ tests for water quality assessment: a case study in Pampean rivers. Wat. Res., 36: 4033-4040. 
GUILLIZONNI, P. 1991. The role of heavy metals and toxic materials in the physiological ecology of submersed macrophytes. Aquat. Bot., 41: 87-109.

INTERNATIONAL ORGANIZATION FOR STANDARDIZATION (ISO). 1987. Water Quality - algal growth inhibition test No. 8692. Paris.

LEWIS, M. A. 1992. Periphyton photosynthesis as an indicator of effluent toxicity: relationship to effects on animal test species. Aquat. Toxicol., 23: 279-288.

LEWIS, M. A. 1993. Freshwater primary producers. In: Handbook of Ecotoxicology, vol 1. Calow P. (ed). Blackwell Scientific Publication, UK.

LEWIS, P.A., D. J. KLEMM \& J. M. LAZORCHAK. 1992. Short term methods for estimating the chronic toxicity of effluents and receiving waters to freshwater organisms. EPA/600/4-91/022

LEWIS, M. A. \& W. WANG. 1997. Water Quality and Aquatic Plants. In: Plants for Environmental Studies. Wuncheng W., Gorsuch J. W. \& Hughes J.S. (eds.). Lewis Publishers, Boca Raton FL pp. 141-175.

MARQUES, M. J., E. MARTINEZ CONDE, J. V. ROVIRA \& S. ORDONEZ. 2001. Heavy metals pollution of aquatic ecosystems in the vicinity of a recently closed underground lead-zinc mine (Basque Country, Spain). Envir:Geol., 40: 1125-1137.

MOHAN, B.S. \& B. B. HOSETTI. 1999. Aquatic plants for toxicity assessment (review). Environ. Res., 81:259-274.

NIYOGI, D. K., W. M. LEWIS \& D. M. McKNIGHT. 2001. Litter breakdown in mountain streams affected by mine drainage: Biotic mediation of abiotic controls. Ecol. Applic., 11: 506-516.
ROSHON, R.D., J. H. MCCANN, D. G. THOMPSON \& G.R. STEPHENSON. 1999. Effects of seven forestry management herbicides on Myriophyllum sibiricum, as compared to other nontarget aquatic organisms. Can. J. For. Res., 29: 1158-1169.

SALT, D.E., M. BLAYLOCK, P. B. A. NANDA KUMAR, V. DUSHENKOV, B. D. ENSLEY, I. CHET \& I. RASKIN. 1995. Phytoremediation: A novel strategy for the removal of toxic metals from the environment using plants. Biotechnol., 13:468-474.

THOMAS, J. M., J. R. SKALSKI, J. F. CLINE, M. C. MCSHANE, W. E. MILTER, S. A. PETERSON, C. A. CALLAHAN \& J. C. GREENE. 1986. Characterization of chemical waste site contamination and determination of its extent using bioassays. Env. Toxicol. Chem., 5: 487-501.

WANG, W. 1992. Use of plants for the assessment of environmental contaminants In: Reviews of Environmental Contamination and Toxicology, vol 126. Ware, G. (ed.). Springer-Verlag, New York Inc. 131 pp.

WEBER, C.I., W. H. PELTIER, T. J. NORBERGKING, W. B. HORNING, F. A. KESSLER, J. R. MENKEDICK, T. W. NEIHEISEL, P. A. LEWIS, D. J. KLEMM, Q. H. PICKERING, E. L. ROBINSON, J. M. LAZORCHAK, L. J. WYMER \& R. W. FREYBERG. 1989. Short-term methods for estimating the chronic toxicity of effluents and receiving waters to freshwater orgunisms. EPA 600/4-89/001. Cincinatti OH: Environmental Monitoring Systems Laboratory. 